ISSN 1112-9867

\title{
STUDYING THE FACTORS AFFECTING URBAN DISPERSION IN MASHHAD METROPOLIS
}

\author{
G. Rabbani Abolfazli ${ }^{1, *}$, M. Rahim Rahnoma ${ }^{2}$ and C. Shafaghi ${ }^{3}$ \\ ${ }^{1} \mathrm{PhD}$ researcher in geography and urban planning, Natural Disasters Engineering Research \\ Institute Index, Isfahan \\ ${ }^{2}$ Professor of Geography and Urban Planning, Ferdowsi University of Mashhad \\ ${ }^{3}$ Professor of geography and urban planning, Natural Disasters Engineering Research Institute \\ Index, Isfahan
}

Published online: 16 July 2016

\begin{abstract}
In recent decades, urban population in the world, especially in southern countries, has exceeded rural population that has brought about urban land expansion followed by dispersion phenomenon, the result of which has created problems in environmental, economic, social, and physical aspects including increased air pollution, potential deterioration within the city, and destruction of farms and open spaces. The aim of this study is to investigate the roots of dispersion in Mashhad metropolis in order to identify solutions to control this problem. The tools used in this research were GIS software for mapping, quantitative methods of Holdren Model, urban primacy index, and area to population growth rate for review and analysis, and at first by examining area to population growth rate, Mashhad- developmental process map, Holdren model, and gross population-density dispersion model of this city was shown.
\end{abstract}

Author Correspondence, e-mail: R_ghazale62@yahoo.com

doi: http://dx.doi.org/10.4314/jfas.v8i2s.122 
Then the roots of dispersion including market failure (checking the price of land), technology, natural population-growth process, and migration were analyzed. To study the dispersion in Mashhad metropolis, Holdren model was used, according to which only $34 \%$ of dispersion is population growth, and $66 \%$ of urban growth is related to horizontal growth. This is indicative of the dispersion in Mashhad metropolis, and the most important reasons are low price of housing in the suburb, ignoring social costs arising from it, increasing percentage of car ownership, gradual population growth in Mashhad due to political priority, and the concentration of facilities in it that are the reason of increase in immigration to this metropolis. To deal with this phenomenon dispersion, it is proposed that patterns of sustainable development such as transportbased development and compact city are used.

Key words: urban dispersion, technology, roots of Mashhad dispersion, the price of land, immigration

\section{INTRODUCTION}

In 2007, the global urban population exceeded the rural population, this new urbanization is the main problem in developing countries, and as estimated, 93 percent of the world's urban population growth in the near future will occur in Asia and Africa. It has caused urban development to open and agricultural spaces causing problems such as increasing use of cars, increasing levels of air pollution, reduced social response, eradication of farms, increased traffic, insecurity, and increase in infrastructure costs. Although there is evidence of how dispersion was formed, its origins are not well documented yet. The main objective of this research is put forward with the question of what are the root of urban sprawl in the metropolis of Mashhad? These reasons are checked to be able to control the problems mentioned.

\section{Background and theoretical foundations}

In the early 1990s, Florida stated urban sprawl with the goal of smart management node or scattered development properties, commercial strip development, expansion of low-density development, and the expansion of the same uses (Ewing, James et al., 2014: 3). In research in an area of the Netherlands from 1994 to 1999, using a multi-functional model that was using the relationship between three variables of land use and determinant social and economicbiophysical factors, Verburg et al (1999) observed that population growth and pressure due to 
that lead to change in land use from agricultural land to industrial and residential ones (Verburg, 1999). Mario believes that the urban sprawl is of the known properties of most cities in developing countries, particularly in Latin America, which shows the vision of poverty, informal settlements, illegal uses of land in the urban peripheries, and severe lack of infrastructure that leads to excessive expansion of cities (Mario, 2001, 32-37). Ewing James defined dispersion as environment where very large population is in a low-density residential development, and separation of houses without flexibility in stores and workplaces has happened, lack of urban centers, dense population and employment and road network characterized by very large-sized blocks and without access from one place to another (Ewing, James et al., 2014: 3). Jackson emphasizes the separation of different uses such as housing, business, and recreational services. Thus, it is strongly makes the society dependent on cars (G. Bishu, 2014). To combat sprawl, Hawkins proposed smart growth that has the policies of complex uses, multi-family housing, cluster development, and the transfer of the right to development (Hawkins, 2014, 2508-25010). Andri defined dispersion as urban development in the periphery that often has negative effects (Afrakhteh and Hajipoor, 2013: 162). Hess says that dispersion means rapid and scattered growth of metropolitan areas and even small cities that in some cases; it extends to rural areas or even village. The use of the term dates back to the mid-twentieth century,when because of improper use of private vehicles and the development of the highway system, expansion of urban spaces in America flourished (Heidari, 2012: 68). Ludlow defined urban sprawl as low-density physical expansion of cities under market conditions, mainly in the agricultural fields (Kamran. et al., 2011: 183). Soul defined dispersion as development without planning, control, and uncoordinated and single uses where there is no mix (Mokhtari et al., 2013).

Mennon offered horizontal dispersion as dispersed self-reliant development towards outside the dense centers of towns and villages along the highways and suburbs outside the city. In another definition, dispersion is a process that occurs because of displacement and relocation of activities from the central city to the periphery (Varethi et al., 2012: 86).According to the results of studies, it can be said that sprawl is a phenomenon caused by management, physical and environmental factors and technology whose characteristics are listed in Table 1. 
Table 1. The characteristics of urban sprawl

\begin{tabular}{|c|c|}
\hline Dimensions & Dispersion characteristics \\
\hline \multirow[t]{7}{*}{ Physical } & Low residential density \\
\hline & Exterior unlimited expansion of new development \\
\hline & Breakdown of land use through zoning \\
\hline & Discrete development \\
\hline & $\begin{array}{l}\text { Extensive commercial strip development along the main } \\
\qquad \text { road }\end{array}$ \\
\hline & The unchecked city spread to surrounding \\
\hline & $\begin{array}{c}\text { Chain road network with many non-detached streets and } \\
\text { sidewalks and barriers for non-car trips }\end{array}$ \\
\hline \multirow[t]{4}{*}{ Management } & $\begin{array}{l}\text { The fragmentation of state power in the land among the } \\
\text { various local governments }\end{array}$ \\
\hline & Decentralization of employment \\
\hline & $\begin{array}{l}\text { Decentralized ownership of land or no land development } \\
\text { plan }\end{array}$ \\
\hline & Combining the formerly separate settlements \\
\hline \multirow[t]{2}{*}{ Environmental } & $\begin{array}{l}\text { Transport surrounded by means of transportation with } \\
\text { personal ownership }\end{array}$ \\
\hline & Early change of use of agricultural and rural lands \\
\hline
\end{tabular}


\begin{tabular}{l|l} 
Technology & Loss of inner half of the city
\end{tabular}

Sources research findings: (Hortas-Rico \& Solé-Ollé, 2010: 1513), (Yu-Hsin Tsai, 2005: 142),

(Ewing, James et al., 2014: 3), (G. Bishu, 2014: 3), (Heidari, 2012: 77), (Aarabi et al., 2011: 5),

(Tavana and Gadermarzi, 121: 2009)

\section{The roots of the dispersion}

In America, after 1950, suburban way of life was facilitated through increased use of cars and expanding highway systems (Goetz, 2013: 2178). According to what Frey says, the flood of minority of downtown (especially black migration from the rural South to the urban centers of Central West shortly after World War II) led the white escape to suburbs during the 1950s (Byun \& X. Esparza, 2005 : 255). According to this study, based on Bain and Esparza, the natural process of migration and ignoring the control of growth of residential development are causing dispersion (Ibid). Heidari has expressed that improper migration to the cities and increasing population growth in cities lead to the expansion of dispersion of cities (Heidari, 2012, 76). According to Brueckner, market failure has established dispersion as follows (Byun \& X. Esparza, 2005: 255.). On the land market, first, the inherent social value of open spaces in agricultural or rural lands is ignored and rural lands, which can act as an open space, have largely become urban land use.

Ewing (1997) emphasizes the result of this market failure in the lack of support for open spaces as a public or semi-public commodity, and secondly, ignoring the social costs such as traffic congestion and air pollution caused by cars. As Ewing mentions, installations created in the countryside are like subsidy for motor vehicles. In other words, suburban residents commute to city centers. However, they do not pay social costs (such as air pollution and traffic congestion) that they have created. Thirdly, the cost of public infrastructure set up by the new development is not fully paid by residents.Habibi and Asadi stated the reasons of dispersion factors such as rising incomes, population growth, and freedom to choose residence, personal car ownership,lack of public transport, taxes in the city center, and the small inner-city apartments (Mokhtari et al., 2013: 68). Taghvayi and Sarayi stated the reasons of dispersion as exogenous and due to oil revenues in the city's economy, intensified investment in urban lands, and especially unused large urban sections, and the negative effects of horizontal expansion of cities (Varethi et al., 2012: 81). 


\section{Solutions to deal with dispersion}

Concerns about the consequences of urban sprawl led to increase of efforts for more dense city and traditional urban development to tackle the dispersion and these solutions, and these solutions describe the kind of development that that has the following features. These are designing street network that uses a shorter length for its traffic flow, a halftone residential high activity in the retail, leisure, and office,mixing most uses that reduce car trips, better access to retail and transport that improves quality of life, and intimate pedestrian-oriented neighborhoods (SONG, 2005, 239).

\section{Research Methodology}

In this study, with the purpose of transparency, relevant literature on urban sprawl and its features and roots were extracted by analysis of conceptual content, and discussed in the metropolis of Mashhad. First, by examining the ratio of area to population growth, the development process map of Mashhad and gross population density of dispersion were shown in this city. Then the causes of the dispersion including market failure, technology, natural population growth and migration trends in land prices indices, the percentage of personal property owned by residents to the population, the volume of daily vehicle trips, the population growth rate of Mashhad, and the immigrants entering Mashhad metropolis over the past 10 years were analyzed. The tools used in this research were GIS software (to show the process of urban development and land prices) and quantitative method of Holdren to determine the ration of horizontal growth of the city's to population growth.

\section{Research variables and indices}

In this study, as shown in the theoretical basis, the criteria extracted that led to urban sprawl were technology, land, population, and migration that include indices outlined in Table 2 and the reasons for these criteria for dispersion are shown in ending row of the table. 
Table 2. Urban Sprawl framework

\begin{tabular}{|c|c|c|c|c|}
\hline Criteria & Technology & Land & Population & Emigration \\
\hline \multirow{3}{*}{ Indices } & $\begin{array}{c}\text { Private } \\
\text { passenger } \\
\text { vehicles } \\
\text { owned by } \\
\text { residents of } \\
\text { Mashhad to } \\
\text { the population }\end{array}$ & \multirow{3}{*}{ Land prices } & $\begin{array}{l}\text { Population } \\
\text { growth rate }\end{array}$ & \multirow{3}{*}{$\begin{array}{l}\text { The number } \\
\text { of immigrants } \\
\text { over the past } \\
10 \text { years }\end{array}$} \\
\hline & \multirow{2}{*}{$\begin{array}{l}\text { The volume of } \\
\text { vehicles on } \\
\text { daily trips on a } \\
\text { typical day }\end{array}$} & & $\begin{array}{c}\text { Gross } \\
\text { population } \\
\text { density }\end{array}$ & \\
\hline & & & $\begin{array}{l}\text { Percent of } \\
\text { area growth } \\
\text { rate to } \\
\text { population }\end{array}$ & \\
\hline Reasons & $\begin{array}{c}\text { The increasing } \\
\text { use of cars and } \\
\text { expanding } \\
\text { highway } \\
\text { systems }\end{array}$ & $\begin{array}{l}\text { Ignoring the } \\
\text { social value } \\
\text { of open } \\
\text { spaces } \\
\text { (ground) }\end{array}$ & $\begin{array}{l}\text { The natural } \\
\text { increase in } \\
\text { population }\end{array}$ & $\begin{array}{l}\text { Migration } \\
\text { from the } \\
\text { countryside to } \\
\text { the cities, } \\
\text { especially } \\
\text { after the } \\
\text { industrial } \\
\text { revolution }\end{array}$ \\
\hline
\end{tabular}

Source: The author, based on research findings

\section{Geographical scope of the research: metropolis of Mashhad}

Sprawl is a phenomenon that happens both in developed and developing countries, but its characteristics, origins, and consequences are different. Iran, as a developing country, which has experienced increasing urbanization in the past decades, has always faced this phenomenon. Urbanization rate (the ratio is obtained by dividing urban population to total population, 
multiplied by 100) in Iran, which was only 31.4 in 1956, exceeded 50 percent in 1986 and reached about 54.3 percent. In the country's last census in 2011 , this ratio was 71.4 (General Population and Housing Census from 1956 to 2011, the Statistical Center of Iran). Following the increase in the urban population, abundance of land in the country is used for it.

Mashhad metropolis that is the second most populous city and capital of Razavi Khorasan province is no exception and in recent decades, as shown in Figure 1, has faced increasing population and area. Percent of population growth rate from 2006 to 2011 against was 2.64, this is while the percentage of city area growth rate is 7.9. Actually, during this five period, the city area has grown about three times the population of the city that we can say: this increase of area growth rate to city population growth has been more than real need of the city that has led to a growing sprawl.

Table 3. Growth rates of area and population of Mashhad

\begin{tabular}{|c|c|c|c|c|c|c|}
\hline Year & $\begin{array}{c}\text { Mashhad } \\
\text { metropolis } \\
\text { population }\end{array}$ & $\begin{array}{c}\text { Metropolis } \\
\text { percent of } \\
\text { population } \\
\text { growth } \\
\text { rate }\end{array}$ & $\begin{array}{c}\text { Area (ha) } \\
\text { of } \\
\text { Mashhad } \\
\text { Metropolis }\end{array}$ & $\begin{array}{c}\text { Percent of } \\
\text { growth rate } \\
\text { of Mashhad } \\
\text { metropolitan } \\
\text { area }\end{array}$ & $\begin{array}{c}\text { Urban } \\
\text { gross land } \\
\text { per capita } \\
\text { of } \\
\text { Mashhad } \\
\text { metropolis }\end{array}$ & $\begin{array}{c}\text { Percent of } \\
\text { population } \\
\text { and area } \\
\text { growths in } \\
\text { Mashhad }\end{array}$ \\
\hline 2006 & 2427316 & 2.64 & 20504 & 7.9 & 0.0084 & 2.99 \\
\cline { 1 - 2 } & 2766258 & 30000 & & 0.0108 & \\
\hline
\end{tabular}

Source: Statistics of Center of Statistics of Iran and Mashhad Municipality 2006-2011 


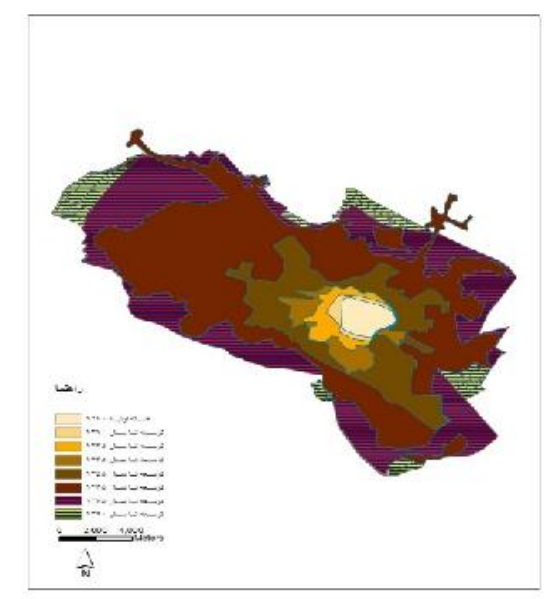

Fig.1. The development process of Mashhad

Reference: Reference location information of comprehensive plan of Mashhad (2011)

\section{Analysis of findings}

\section{Holdren Model}

One of the basic methods for determining urban ungainly growth is using Holdren Model. John Holdren (1991) used a method to determine the horizontal growth of the city and population growth. Using this method, one can determine how much of the urban growth results from population growth and how much was from ungainly growth of the city. He has used gross land per capita formula in this method (Hekmatnia and Mousavi, 2006, 131).

$\ln \left(\frac{\text { population of the end }}{\text { population of the start }}\right)+\ln \left(\frac{\text { End per capita gross }}{\text { Strat per capita gross }}\right)=\ln \left(\frac{\text { City area at the end }}{\text { City area at the start }}\right)$ In other words, the ratio of natural logarithm of population of the end to the start of the period plus the natural logarithm of per capita of the end to the start will be equal to ratio of the natural logarithm of the area of the city at the end to the start (Hekmatnia, 2006, 131).

Holdren model from 2006 to 2011, for Mashhad will be as follows:

$$
\ln \left(\frac{2766258}{2427316}\right)+\ln \left(\frac{0.0108}{0.0084}\right)=\ln \left(\frac{30000}{20504}\right)
$$

$0.13+0.25=0.38$

$$
\begin{gathered}
\frac{0.13}{0.38}+\frac{0.25}{0.38}=\frac{0.38}{0.38} \\
0.34+0.66=1
\end{gathered}
$$


Therefore, physical growth in Mashhad from 2006 to 2011 has only been 34 percent due to population growth, and $66 \%$ of city-growth is due to horizontal and dispersed growth of the city, the result of which has been the reduction of gross population density and per capita gross increase of urban land.

\section{Gross population density}

As shown in Table 4, gross population density has decreased in this period, and its value for Mashhad from 118.3 people per hectare in 2006 reached 92.2 people per hectare in 2011 that has led to the population dispersion in more area and thereby the phenomenon of urban sprawl.

Table 4. Gross population density

\begin{tabular}{|c|c|}
\hline Year & $\begin{array}{c}\text { Gross population density } \\
\text { (persons per ha) }\end{array}$ \\
\hline 2006 & 118.3 \\
\hline 2011 & 92.2 \\
\hline
\end{tabular}

Source: the author based on Statistics of Center of Statistics of Iran and Mashhad

The roots of urban sprawl in Mashhad

As mentioned in the theoretical foundations of the roots of dispersion in cities around the world, especially America, here the reasons of market failure, technology, migration, and natural process are discussed.

\section{Market failure}

Low economic strata that do not have the power of land purchase and settlement in the center of town, to use the utilities are forced to choose to live farther out. In Figure 2, it is seen that as we get farther from the city center, land prices reducesand on the fringes of the city, we have the minimum price of land. As a result, in this way, using cars has increased in the marginalized areas, social cost, and public infrastructure costs resulting from that are not paid by the actual amount by the residents of the suburbs. 


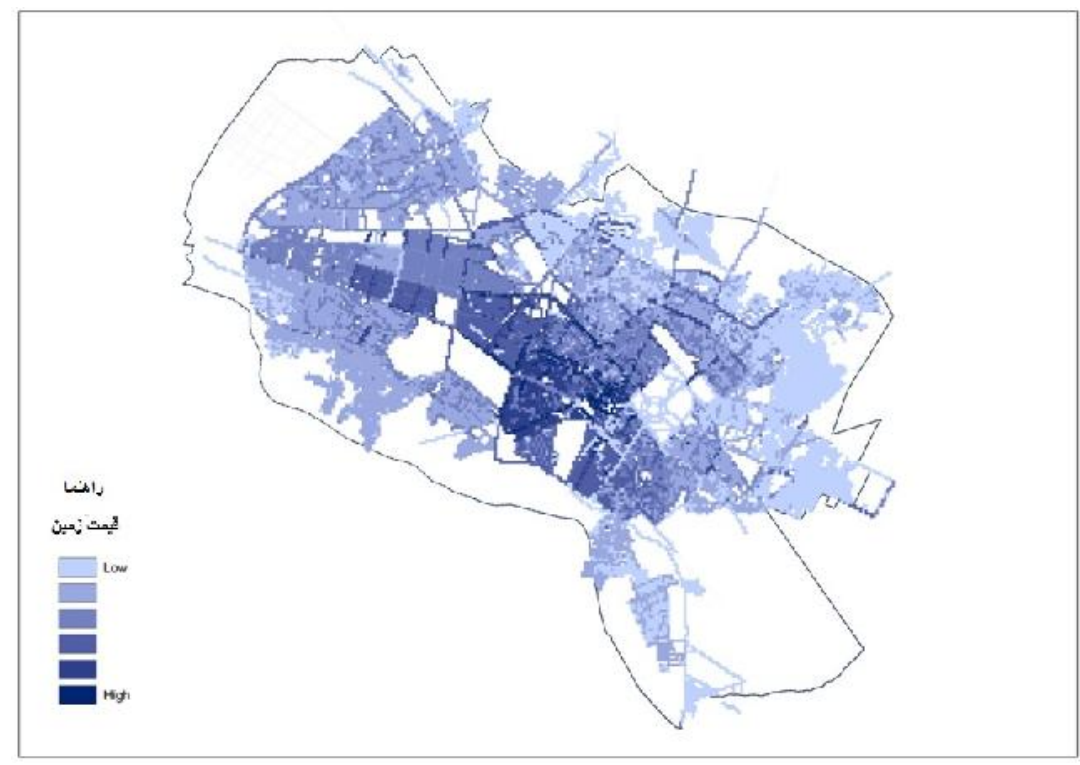

Fig.2. land price

Source: author based on reference location information based on a comprehensive plan of Mashhad (2011)

\section{Technology}

Car is one of the factors, which due to facilitating movement within the city and easier access of citizens to various parts of the city, in particular, from marginalized and remote areas to urban centers causes the sprawl phenomenon. Comparing the percent of car ownership from 2006 to 2011 shows an increase of $3 \%$ of this rate. Moreover, comparing the volume of vehicles on daily trips on one day between 2006 and 2011 shows an increase in this number from 2194216 to 3591732, which as is seen, 1397516 trips have been added to this number. Thus, increase of the above values in Mashhad metropolis leads to sprawl phenomenon. 
Table 5. The percent of private passenger vehicles owned by residents of Mashhad population (2006-2011)

\begin{tabular}{|c|c|}
\hline \multicolumn{2}{|c|}{ The percent of private passenger vehicles owned by residents } \\
\hline Percent & Year \\
\hline 9 & 2006 \\
\hline 12 & 2011 \\
\hline
\end{tabular}

Source: Statistical Yearbook of Transport and Traffic calculation of Mashhad from 2006 to 2011

Table 6. The volume of vehicles on daily trips on a typical day (2005-2011)

\begin{tabular}{|c|c|c|}
\hline \multicolumn{2}{|c|}{ The volume of vehicles on daily trips on a typical day } \\
\hline Year & 2006 & 2011 \\
\hline Personal cars & 1162518 & 2561666 \\
\hline $\begin{array}{c}\text { Taxis and passenger } \\
\text { vehicles }\end{array}$ & 928715 & 946838 \\
\hline Pickups & 102983 & 83228 \\
\hline Total & 2194216 & 3591732 \\
\hline
\end{tabular}

Source: Statistical Yearbook of Transport and Traffic calculation of Mashhad from 2006 to 2011

\section{Natural process}

A gradual increase in the population of the central city and the priority of selected administrative-political areas, concentration of its resources, and on the other hand, the neglect of the periphery and consequently, a drop in living conditions in the countryside lead to the formation of an accelerated process of population going to the central city in search of job opportunities (Sarafi, 2005,60).

Mashhad metropolis population-growth in recent decades and consequently polarization of Mashhad metropolis, which is 0.82 with urban primacy index (which is obtained by the division of the first city into the first, second, third and fourth in the province),show the super superiority 
of this city compared to the other cities of Khorasan Razavi province. Immigrants who are unable to provide affordable housing in the legal range of the city, to gain civil service, inevitably have to reside in informal settlements on the outskirts of cities that leads to urban sprawl.

Table 7. Population growth rates in Mashhad

\begin{tabular}{|c|c|c|}
\hline $\begin{array}{c}\text { Immigration } \\
\text { percent }\end{array}$ & \multicolumn{2}{|c|}{ Population growth rates in Mashhad } \\
\hline \multirow{2}{*}{0.1} & $2006-2011$ & $1996-2006$ \\
\cline { 2 - 3 } & 2.64 & 2.54 \\
\hline
\end{tabular}

Source: The author using Mashhad Municipality information

\section{Emigration}

As shown in the literature, migration causes urban sprawl. In Mashhad metropolis, extensive migrations have occurred due to the migration of Afghans, regional financial poverty, lack of water and agricultural land, search for better jobs, and natural disasters such as droughts that are the main reasons of urban population increase and consequently expansion of the city limits, so that the annual population growth rate is about 5.3\% in years 1976 to 1996 (2.6 times of Tehran) (Rahnoma, 2011, 180). Since 2001 to 2006, the number of immigrants is 242918, while this number in 2006-2011 reaches 407680 that are almost double in the previous period that has brought about dispersion in Mashhad.

Table 8. The rate of immigration

\begin{tabular}{|c|c|}
\hline \multicolumn{2}{|c|}{ Immigrants to Mashhad metropolis during the past 10 years } \\
\hline 242918 & $2001-2006$ \\
\hline 407680 & $2006-2011$ \\
\hline
\end{tabular}

Source: Statistics Institute of Iran 2006 and 2011

\section{CONCLUSION}

In recent decades, with the rise in urban population in Iran, urban lands have expanded to agricultural lands and open spaces and urban sprawl phenomenon has occurred. In this study, first, the existence of dispersion phenomenon in the metropolis of Mashhad was studied that from 2006 to 2011, according to Holdren Model, is only 34 percent due to population growth, 
and 66 percent of the growth of the city is due to horizontal growth that represents the dispersion phenomenon in Mashhad. Then by proving the existence of dispersion in Mashhad, the roots of its existence were analyzed. The variables of personal passenger vehicles owned by residents of Mashhad population, the volume of daily vehicle trips on a typical day, the price of land, population growth, natural increase of population, the number of immigrants over the past 10 years were extracted according to the theoretical foundations and were assessed between 2006 to 2011 in Mashhad. The percentage of personal passenger vehicles owned by residents to the population has had increase of three percent. The volume of vehicles on daily trips per day has increased from 2194216 to 3591732 . Population growth rate has changed from 2.54 in 19962006 to 2.64 percent and has had one percent growth. The number of immigrants from 2001 to 2006 is 242918 while this number in 2006-2011 has increased to 407680 that is nearly doubled. Regarding the price of land, land prices reduce by getting away from the city center and outskirts have the lowest land prices. These variables as shown lead to formation and growth of sprawl phenomenon in Mashhad metropolis. To deal with this problem, it is proposed to use sustainable development models, such as transportation-based development and compact city. The importance of this research is in revealing the roots of urban sprawl that can be used to deal with it in the future plans of Mashhad metropolis.

\section{REFERENCES}

1. Afrakhteh, H. Hajipoor, M. Urban sprawl and its consequences in Sustainable Rural Development (Case Study: Birjand surrounding villages), International Journal of Geographic Society, 2013, 39: 158-185.

2. Hekmatnia, H. Mousavi, M. The use of models in geography with an emphasis on urban and regional planning. Elm and Novin Publications, 2006.

3. Heydari, A. The space-physical analysis of future development of smart urban growth Saqez with an emphasis on using the Shannon entropy, the Journal of Geography and Urban Development, 2012, 2: 67-94.

4. Rahnoma, M. The final report of a research project studies the metropolitan land use plan Mashhad, Mashhad Municipality, 2011.

5. Statistical Yearbook of Mashhad (2006-2011) Mashhad Municipality

6. Traffic and Transport Mashhad (2006-2011) The second transport statistics of Mashhad 
7. Sarrafi, M. Muhammadi, A. The formation and expansion of informal settlements, causes, challenges, and strategies Case study: Trans neighborhood in the city, Journal of Earth Sciences, 2005 , 11: $59-79$

8. Zarabi, A. Saberi, H. Smart urban growth spatial analysis (Case Study: Isfahan districts), Research in Human Geography, 2011, 77: 1-7.

9. Zia, T. Qadermazi, M. Changes in land use in rural villages around the cities in the process of urban sprawl of Niser and Hassan Abad, human geography research, 2009, 68: 119-135

10. Azizi, M., Arasteh, M. Explaining of the urban front of the building density index (case study in Yazd), the identity of the city, 2011, 8: 5-15.

11. Kamran, H. Varethi, H. Parizadi, T., Hosseini Amini, H. Examining the role of physical development projects in urban sprawl with passive defense approach, Journal of Geography and Regional Development, 2011, 17: 179-209

12. Mokhtari, R. Hossein Zadeh, R., Safar Ali Zadeh, A. The analysis of smart urban growth patterns in fourteen areas of Isfahan based on the model of regional planning, urban and regional studies, 2013 , 19: 65 -82.

13. Statistical Center of Iran (2006-2011) General Population and Housing Census

14. Faranhad Consulting Engineers (2010) The comprehensive plan in Mashhad

15. Varthi, H. Rajai Jezzine, A. Ghanbari, M. (2012) Analysis of Factors Urban Sprawl and Physical growth Ghonabad using entropy models and Holdren (11), 79-100

16. Arribas-Bel, D., Nijkamp, P. \& Scholten , H. Multidimensional urban sprawl in Europe: A self-organizing map approach,Computers, Environment and Urban Systems, 2011, 35: 263275

17. Bier, T.URBAN SPRAWL AND DECLINE Prospects for Change, Public works management \& policy, 2001, 6(2): 83-87

18. Bishu, S. Collective Versus Individual Gain of "Natural Sprawl": A Response to OkuliczKozaryn's Article on "Natural Sprawl”, Administration \& Society, 2014: 1-8.

19. Byun,p., Esparza,A. A Revisionist Model of uburbanization and Sprawl The Role of Political Fragmentation, Growth Control, and Spillovers, Journal of Planning Education and Research, 2005, 24: 252-264

20. Downs, A. Some realities about sprawl and urban decline. Brookings Institution; Washington, DC, 1999. 
21. Ewing, R. Hamidi, S. Grace, J: Urban sprawl as a risk factor in motor vehicle crashes, Urban Studies, 2014, 1-20.

22. Goetz, A. Suburban Sprawl or Urban Centres: Tensions and Contradictions of Smart Growth Approaches in Denver, Colorado, Urban Studies, 2013, 50(11): 2178-2195

23. Galster, G., Hanson, R., Ratcliffe, M., Wolman, H., Coleman, S., \& Freihage, J. Wrestling Sprawl to the Ground: Defining and Measuring an Elusive Concept, Housing Policy Debate, 2001, 12(4): 681-718

24. Hawkins, C. Competing interests and the political market for smart growth policy, Urban Studies, 2014, 51(12), 2503-2522

25. Hesse, J., Lathrop, R. A Housing-Unit-Level Approach to Characterizing Residential Sprawl, Photogrammetric Engineering \& Remote Sensing, 2003, 69(9): 1021-1030.

26. Hortas-Rico, M, Does Urban Sprawl Increase the Costs of Providing Local Public Services? Evidence from Spanish Municipalities, Urban Studies, 2010, 47(7), 1513-1514

27. Lungo, M. Urban Sprawl and Land Regulation in Latin America, Land Lines, 2001, 13( 2): 28-39.

28. Verburg, V. Veldkamp, T. Bouma, J. (1999). Land use

29. change under conditions of high population pressure: the case of Java, Global Environmental Change, 9(4), 303-312

30. Richardson, H., Gordon, P. U.S. Population and Employment Trends and Sprawl Issues, Urban sprawl in western Europe and united states, Aldershot, 1997, 217-236.

31. Sierra Club(1999). Sprawl: The Dark Side of the AmericanDream, Report 98, Sierra Club,SanFrancisco,California

32. Song, Y. SMART GROWTH AND URBAN DEVELOPMENT PATTERN:A COMPARATIVE STUDY, INTERNATIONAL EGIONAL SCIENCE REVIEW, 2005, 28( 2): 239-265

33. Tsai, Y. Quantifying Urban Form: Compactness versus 'Sprawl', Urban Studies, 2005, 42(1): 141-161 
How to cite this article:

Rabbani Abolfazli G, Rahim Rahnoma M, Shafaghi C. Studying the factors affecting urban dispersion in mashhad metropolis. J. Fundam. Appl. Sci., 2016, 8(2S), 1812-1828. 